\title{
Karakteristik dan kualitas hidup pasien Penyakit Paru Obstruksi Konik (PPOK)
}

\author{
Ahmad Asyrofy ${ }^{1}$, Triana Arisdiani ${ }^{2}$, Moch Aspihan $^{3 *}$ \\ ${ }^{1,2}$ Sekolah Tinggi Ilmu Kesehatan Kendal, Indonesia. \\ ${ }^{3}$ Fakultas Ilmu Keperawatan, Universitas Islam Sultan Agung Semarang, Indonesia \\ *Coresponding Author: aspihan@unissula.ac.id
}

\begin{abstract}
Abstrak
Pendahuluan: Penyakit paru obstruktif kronik (PPOK) merupakan salah satu penyebab utama morbiditas dan mortalitas di seluruh dunia, prevalensi internasioanl dari Global Initiative Fot Chronic Obstructive Lung Disease (GOLD) stage II dan lebih tinggi diperkirakan sekitar $10 \%$ dimana angka ini terus meningkat secara bertahap. PPOK berpotensi menimbulkan ketidakcukupan oksigen karena adanya kerusakan pada alveolar serta perubahan fisiologi pernapasan sehingga terjadi keterbatasan saluran nafas. Pasien PPOK cenderung mengalami dispnea dan kelemahan fisik yang berdampak buruk terhadap kualitas hidupnya. Tujuan penelitian untuk mendeskripsikan karakteristik dan kualitas hidup pasien penyakit paru obstruksi kronik (PPOK). Metode: Desain penelitian adalah deskriptif. Populasi penelitian ini adalah pasien PPOK dengan sampel sebanyak 51 yang diambil secara convinience di RSUD dr H Soewondo Kendal. Alat ukur penelitian berupa COPD Assesment Test (CAT). Analisis data meliputi analisis univariat dan analisis bivariat menggunakan korelasi Pearson dan atau alternatifnya yaitu Kendall-tau. Hasil: Pasien PPOK sebagian besar adalah laki-laki (57,1\%), umur median 45 tahun, paling banyak berpendidikan SMP (30,4\%), paling banyak memiliki pekerjaan swasta $(42,9 \%)$, lama menderita PPOK median 1 tahun, frekuensi napas rerata 23,6 permenit, komorbiditas terbanyak adalah jantung dan hipertensi (37,5\%), bentuk torak terbanyak normal (82,1\%), dan sebagian besar merokok (57,1\%). Skor Chronic Obstructive Pulmonary Disease Assesment Test (CAT) rerata 22,6. Kategori kualitas hidup pasien PPOK sebagian besar adalah buruk (60,7\%). Simpulan: Tidak ada perbedaan kualitas hidup pada jenis kelamin, umur, lama menderita, dan merokok pada pasien PPOK.
\end{abstract}

Kata kunci: Karakterisitk pasien; kualitas hidup; PPOK

\section{Characteristics and quality of live on Chronic Obstructive Pulmonary Disease (COPD) patients}

\begin{abstract}
Introduction: Chronic obstructive pulmonary disease (COPD) is one of the leading causes of morbidity and mortality in worldwide, the international prevalence of the Global Initiative For Chronic Obstructive Lung Disease (GOLD) stage Il and higher is estimated at around 10\% where this rate continues to increase gradually. COPD has the potential to cause oxygen insufficiency due to alveolar damage and changes in respiratory physiology, resulting in airway limitations. COPD patients tend to experience dyspnea and physical weakness which adversely affects their quality of life. Aim of this study was to describe the characteristics and quality of life of patients with chronic obstructive pulmonary disease (COPD). Methods: The research design was descriptive. The study population was COPD patients with sample of 51 taken by convenience at the Dr. H Soewondo Kendal Regional Hospital. The research measurement tool was the COPD Assessment Test (CAT). Data analysis included univariate and bivariate analysis using Pearson correlation and or the alternative, Kendall-tau. Results: Most of COPD patients were male (57.1\%), median age 45 years, most had junior high school education (30.4\%), most had private jobs (42.9\%), median 1 years, the average respiratory rate was 23.6 per minute, the most comorbidities were heart disease and hypertension (37.5\%), most of the thoracic shape was normal (82.1\%), and most of them smoked (57.1\%). The mean score of Chronic Obstructive Pulmonary Disease Assessment Test (CAT) was 22.6. The quality of life category for COPD patients was mostly poor (60.7\%). Conclusions: There is no differences between quality of life in gender, age, duration of suffering, and smoking.
\end{abstract}

Keywords: Patient characteristics; quality of life; COPD

How to Cite: Asyrofy, A., Arisdiani, T., \& Aspihan, M. (2021). Karakterisitik dan kualitas hidup pasien Penyakit Paru Obstruksi Kronik (PPOK). NURSCOPE: Jurnal Penelitian dan Pemikiran Ilmiah Keperawatan, 7 (1), 13-21 


\section{PENDAHULUAN}

Penyakit paru obstuksi kronik (PPOK) menjadi masalah kesehatan dunia seiring dengan perkembangan dampak polusi lingkungan dan gaya hidup. Data WHO menunjukkan bahwa PPOK telah mengakibatkan lebih dari 3 juta orang meninggal dunia pada tahun 2012 atau sebesar $6 \%$ dari total kematian di dunia pada tahun tersebut. Angka kejadian PPOK di dunia sangat tinggi sehingga pada tahun 2020 PPOK diperkirakan menempati urutan kelima penyakit yang akan diderita di seluruh dunia (GOLD, 2020a).

PPOK merupakan penyakit yang menempati urutan ke empat penyebab kematian di Indonesia. PPOK menjadi urutan pertama pada kelompok penyakit paru di Indonesia dengan angka kesakitan (35\%). Peningkatan angka kejadian PPOK disebabkan karena penuaan penduduk serta paparan faktor resiko PPOK. Penyakit Paru Obstruktif Kronik (PPOK) adalah penyakit yang umum dapat dicegah dan diobati dengan karakteristik gejala pernapasan dan hambatan aliran udara yang persisten yang diakibatkan oleh abnormalitas saluran napas dan/atau alveolus yang biasanya disebabkan oleh paparan partikel yang berbahaya atau gas yang signifikan (GOLD, 2020a).

Laporan dari Global Initiative for Chronic Obstructive Lung Disease (GOLD, 2020a)menyebutkan bahwa pada tahun 2010 sebanyak 384 juta orang atau sekitar 11,7\% penduduk dunia merupakan penderita PPOK dengan angka kematian mencapai tiga juta orang tiap tahunnya. Tahun 2011, PPOK tercatat sebagai penyebab kematian tertinggi ketiga di Amerika Serikat dan pada tahun 2030 nantinya, diestimasikan angka kematian akibat PPOK akan meningkat mencapai 4,5 juta orang tiap tahunnya (GOLD, 2020a). World Health Organization (WHO) sendiri menyebutkan bahwa pada tahun 2020, PPOK akan menjadi penyebab kematian tertinggi ketiga di seluruh dunia. (WHO, 2017).

Penyakit paru obstruktif kronik (PPOK) merupakan salah satu penyebab utama morbiditas dan mortalitas di seluruh dunia, prevalensi internasioanl dari Global Initiative Fot Chronic Obstructive Lung Disease (GOLD) stage II dan lebih tinggi diperkirakan sekitar $10 \%$ dimana angka ini terus meningkat secara bertahap. PPOK berpotensi menimbulkan ketidakcukupan oksigen pada penderitanya. PPOK merupakan salah satu penyakit kronik yang ditandai dengan terbatasnya aliran udara di saluran pernapasan. PPOK dapat mengakibatkan gangguan pada proses oksigenisasi keseluruhan anggota tubuh karena adanya kerusakan pada alveolar serta perubahan fisiologi pernapasan. Kerusakan dan perubahan tersebut dapat menyebabkan inflamasi pada bronkus dan mengakibatkan terjadinya kerusakan pada dinding bronkiolus terminalis serta menimbulkan obstruksi atau penutupan awal fase eksprirasi sehingga terjadi keterbatasan saluran nafas yang tidak sepenuhnya reversible yang berhubungan dengan respon inflamasi.

Karakteristik pasien PPOK sebanyak $80,6 \%$ adalah laki-laki, dan sebanyak $66,7 \%$ berusia $51-70$ tahun (Tarigan \& Juliandi, 2018). Hasil studi lainnya menunjukkan keselarasan yaitu sebanyak 60,96\% pasien PPOK adalah laki-laki (ROSHA, 2017). Pasien PPOK sebagian besar (> 53\%) memiliki riwayat merokok (Huriah \& Ningtias, 2017; Tarigan \& Juliandi, 2018). Sedikit berbeda dengan hasil studi lain yang menunjukkan sebanyak 45,89\% pasien PPOK tidak memiliki kebiasaan merokok (ROSHA, 2017).

Kondisi ketidakcukupan oksigenasi pada pasien PPOK akan berdampak negatif terhadap kualitas hidupnya. Hasil studi terdahulu menunjukkan $43,3 \%$ pasien PPOK mengalami kualitas hidup yang buruk (Ritianingsih, 2017). Hasil studi lainnya menunjukkan perbedaan bahwa sebanyak $71,92 \%$ pasien PPOK mengalami kualitas hidup yang baik (ROSHA, 2017).

Upaya pencegahan dan mengurangi gejala yang timbul pada penderia PPOK dapat dilakukan dengan cara pengobatan farmakologis, dimana pengobatan tersebut bersifat jangka panjang. Selain pengobatan farmkologis, terdapat pengobatan non-farmakologi yang dapat dilakukan oleh tenaga 
kesehatan dan juga oleh penderita itu sendiri, dimana perawatan tersebut diperoleh dari edukasi dan latihan yang telah diajarkan oleh profesional kesehatan salah satunya adalah perawat.

Tujuan penelitian ini adalah untuk mengeksplorasi tingkat kualitas hidup pasien PPOK. Tujuan khusus penelitian ini adalah untuk 1) Mendeskripsikan karakteristik pasien PPOK; 2) Mendeksripsikan kualitas pasien PPOK; 3). Menganalisa perbedaan kualitas hidup pada jenis kelamin, umur, lama menderita, dan tindakan merokok.

\section{METODE}

Desain penelitian adalah deskriptif. Populasi penelitian ini adalah pasien PPOK di wilayah Kabupaten Kendal, sampel sebanyak 51 yang diambil secara convinience di RSUD dr H Soewondo Kendal denghan kriteria inklusi sampel yaitu pasien PPOK usia dewasa $>18$ tahun sampai 60 tahun. Penelitian dilaksanakan Bulan Maret sampai dengan Mei 2020. Alat ukur penelitian ini menggunakan kuesioner COPD Assesment Test (CAT). Alat ukur penelitian tersebut merupakan alat ukur yang telah teruji validitas dan reliabilitasnya dan telah banyak digunakan di dunia internasional untuk mengukur variabel tersebut. CAT telah digunakan dalam menilai perubahan kualitas hidup dan luaran program rehabilitasi paru pasca kejadian eksaserbasi akut serta untuk menilai derajat keparahan eksaserbasi akut (Morishita-Katsu et al., 2016). Tahapan pengumpulan data sebagai berikut: (1) mengidentifikasi calon sampel kelompok kasus dan kelompok; (2) melakukan informed consent penelitian; (3) mengukur karakteristik dan kualitas hidup menggunakan kuesioner CAT. ; (4) Melakukan pengolahan data; (5) Melakukan analisis data dan interpretasi hasil penelitian. Analisis data meliputi analisis univariat dan analisis bivariat. Analisis univariat mendeskripsikan variabel-variabel penelitian menggunakan tendensi sentral dan variasi pada variabel numerik, serta analisis proporsi pada variabel kategorik, sedangkan analisis bivariat menggunakan korelasi Pearson dan atau alternatifnya yaitu Kendall-tau.

Tabel 1. Analisis Univariat

\begin{tabular}{llll}
\hline No & \multicolumn{1}{c}{ Variabel } & \multicolumn{1}{c}{ Skala } & \multicolumn{1}{c}{ Analisis Statistik } \\
\hline 1 & Usia & Interval & Tendensi sentral dan variasi \\
2 & Jenis kelamin & Nominal & Proporsi \\
3 & Pendidikan & Ordinal & Proporsi \\
4 & Pekerjaan & Nominal & Proporsi \\
5 & Komorbiditas & Nominal & Proporsi \\
6 & Lama menderita PPOK & Interval & Tendensi sentral dan variasi \\
7 & Merokok & Nominal & Tendensi sentral dan variasi \\
8 & Bentuk torak & Nominal & Proporsi \\
9 & Frekuensi napas & Interval & Tendensi sentral dan variasi \\
10 & Kualitas hidup & Interval & Tendensi sentral dan variasi \\
\hline
\end{tabular}

Tabel 2. Analisis Bivariat

\begin{tabular}{|c|c|c|c|c|c|}
\hline No & Variabel & Skala & & Skala & Analisis Statistik \\
\hline 1 & Usia & Interval & Kualitas hidup & Ordinal & Kendalls-tau \\
\hline 2 & Jenis kelamin & Nominal & & & Mann-Whitney \\
\hline 3 & Lama menderita & Interval & & & Kendalls-tau \\
\hline 4 & Merokok & Nominal & & & Mann-Whitney \\
\hline
\end{tabular}

Penelitian ini menerapkan prinsip etik penelitian sebagai berikut: (1) Beneficience meliputi: the right to protection from exploitation dan the right to freedom from harm and discomfort; (2) Respect for human dignity meliputi: the right to self-determination dan the right to full disclosure; (3) Justice meliputi: the right to fair treatment the right to privacy. 


\section{HASIL DAN PEMBAHASAN}

Deskripsi karakteristik dan kualitas hidup pasien PPOK meliputi: umur, jenis kelamin, pendidikan, pekerjaan, lama PPOK, komorbiditas, bentuk torak, frekuensi napas, dan merokok. Pasien PPOK berumur median 45 tahun, usia termuda 21 tahun dan usia tertua 60 tahun. Lama menderita PPOK median 1 tahun, paling sedikit 1 tahun dan paling lama 4 tahun. Frekuensi napas pasien PPOK rerata 23,6 permenit, paling sedikit 14 permenit dan terbanyak 31 permenit. Informasi selengkapnya terdapat pada tabel 3 di bawah ini.

Tabel 3. Karakteristik Umur, Lama, dan Frekuensi Napas Pasien PPOK ( $n=56)$

\begin{tabular}{lccccc}
\hline & Rerata & SD & Median & Min - Maks & $\mathbf{9 5 \% ~ C l}$ \\
\hline Umur & 42,7 & 13,3 & 45 & $21-60$ & $39,2-46,3$ \\
Lama PPOK & 1,6 & 0,8 & 1 & $1-4$ & $1,4-1,8$ \\
Frekuensi Napas & 23,6 & 3,4 & 24 & $14-31$ & $22,7-24,5$ \\
\hline
\end{tabular}

Pasien PPOK sebagian besar adalah laki-laki $(57,1 \%)$, paling banyak berpendidikan SMP $(30,4 \%)$, paling banyak memiliki pekerjaan swasta $(42,9 \%)$, komorbiditas terbanyak adalah jantung dan hipertensi $(37,5 \%)$, bentuk torak terbanyak adalah normal $(82,1 \%)$, dan sebagian besar merokok $(57,1 \%)$. Informasi selengkapnya terdapat pada tabel 4 dan 5 di bawah ini.

Tabel 4. Karakteristik Jenis Kelamin, Pendidikan, dan Pekerjaan Pasien PPOK $(n=56)$

\begin{tabular}{lcc}
\hline \multicolumn{1}{c}{ Variabel } & $\mathbf{n}$ & $\mathbf{\%}$ \\
\hline Jenis Kelamin & 32 & 57,1 \\
Laki-laki & 24 & 42,9 \\
Perempuan & & \\
Pendidikan & 7 & 12,5 \\
Tidak Sekolah & 12 & 21,4 \\
SD & 17 & 30,4 \\
SMP & 13 & 23,2 \\
SMA & 7 & 12,5 \\
Perguruan Tinggi & & \\
Pekerjaan & 24 & 42,9 \\
Swasta & 16 & 28,6 \\
Wiraswasta & 16 & 28,6 \\
Tidak bekerja & & \\
\hline
\end{tabular}

Tabel 5. Karakteristik Komorbiditas, Bentuk Torak, dan Tindakan Merokok Pasien PPOK ( $n=56)$

\begin{tabular}{lcc}
\hline \multicolumn{1}{c}{ Variabel } & $\mathbf{n}$ & $\%$ \\
\hline Komorbiditas & 16 & 28,6 \\
Anemia & 12 & 21,4 \\
Diabetes Melitus & 1 & 1,8 \\
Diabetes Melitus, Anemia & 1 & 1,8 \\
Hipotensi & 21 & 37,5 \\
Jantung dan hipertensi & 1 & 1,8 \\
Kolestrol & 1 & 1,8 \\
Stroke & 3 & 5,4 \\
Tidak ada & & \\
Bentuk Torak & 6 & 10,7 \\
Barel & 4 & 7,1 \\
Funnel & 46 & 82,1 \\
$\quad$ Normal & & \\
Merokok & 32 & 57,1 \\
$\quad$ Merokok & 24 & 42,9 \\
$\quad$ Tidak merokok & & \\
\hline
\end{tabular}


Tabel 6. Deskripsi Butir-butir CAT Pasien PPOK $(n=56)$

\begin{tabular}{|c|c|c|c|c|c|c|c|}
\hline & 0 & 1 & 2 & 3 & 4 & 5 & \\
\hline $\begin{array}{l}\text { Saya tidak } \\
\text { pernah batuk }\end{array}$ & $1(1)$ & $1(1)$ & $\begin{array}{c}15 \\
(26,8)\end{array}$ & $\begin{array}{c}17 \\
(30,4)\end{array}$ & $16(28,6)$ & $\begin{array}{c}6 \\
(10,7)\end{array}$ & $\begin{array}{l}\text { Saya selalu } \\
\text { batuk }\end{array}$ \\
\hline $\begin{array}{l}\text { Tidak ada dahak } \\
\text { (riak) sama sekali }\end{array}$ & $1(1,8)$ & $8(14,3)$ & $\begin{array}{c}13 \\
(23,2)\end{array}$ & $\begin{array}{c}24 \\
(42,9)\end{array}$ & $7(12,5)$ & $3(5,4)$ & $\begin{array}{l}\text { Dada saya } \\
\text { penuh dengan } \\
\text { dahak }\end{array}$ \\
\hline $\begin{array}{l}\text { Tidak ada rasa } \\
\text { berat (tertekan) } \\
\text { di dada }\end{array}$ & $1(1,8)$ & $8(14,3)$ & $\begin{array}{c}12 \\
(21,4)\end{array}$ & $\begin{array}{c}19 \\
(33,9)\end{array}$ & $13(23,3)$ & $3(5,4)$ & $\begin{array}{l}\text { Dada saya } \\
\text { terasa berat } \\
\text { (tertekan) } \\
\text { sekali }\end{array}$ \\
\hline $\begin{array}{l}\text { Ketika saya jalan } \\
\text { mendaki/naik } \\
\text { tangga saya tidak } \\
\text { sesak }\end{array}$ & $2(3,6)$ & $5(8,9)$ & $14(25)$ & $\begin{array}{c}22 \\
(39,3)\end{array}$ & $8(14,3)$ & $5(8,9)$ & $\begin{array}{l}\text { Ketika saya } \\
\text { jalan } \\
\text { mendaki/naik } \\
\text { tangga, saya } \\
\text { sangat sesak }\end{array}$ \\
\hline $\begin{array}{l}\text { Aktifitas sehari- } \\
\text { hari saya di } \\
\text { rumah tidak } \\
\text { terbatas }\end{array}$ & $2(3,6)$ & $\begin{array}{c}10 \\
(17,9)\end{array}$ & $\begin{array}{c}10 \\
(17,9)\end{array}$ & $\begin{array}{c}19 \\
(33,9)\end{array}$ & $12(21,4)$ & $3(5,4)$ & $\begin{array}{l}\text { Aktifitas } \\
\text { sehari-hari } \\
\text { saya di rumah } \\
\text { sangat } \\
\text { terbatas }\end{array}$ \\
\hline $\begin{array}{l}\text { Saya tidak } \\
\text { khawatir keluar } \\
\text { rumah meskipun } \\
\text { saya menderita } \\
\text { penyakit paru }\end{array}$ & $5(8,9)$ & $2(3,6)$ & $\begin{array}{c}6 \\
(10,7)\end{array}$ & $\begin{array}{c}21 \\
(37,5)\end{array}$ & $19(33,9)$ & $3(5,4)$ & $\begin{array}{l}\text { Saya sangat } \\
\text { khawatir } \\
\text { keluar rumah } \\
\text { karena kondisi } \\
\text { paru paru }\end{array}$ \\
\hline $\begin{array}{l}\text { Saya dapat tidur } \\
\text { dengan nyenyak }\end{array}$ & $0(2)$ & $\begin{array}{c}10 \\
(17,9)\end{array}$ & $14(25)$ & $\begin{array}{c}16 \\
(28,6)\end{array}$ & $11(19,6)$ & $3(5,4)$ & $\begin{array}{l}\text { Saya dapat } \\
\text { tidur nyenyak } \\
\text { karena kondisi } \\
\text { paru saya }\end{array}$ \\
\hline $\begin{array}{l}\text { Saya sangat } \\
\text { bertenaga }\end{array}$ & $3(5,4)$ & $8(14,3)$ & $\begin{array}{c}9 \\
(16,1)\end{array}$ & $\begin{array}{c}11 \\
(19,6)\end{array}$ & $18(32,1)$ & $\begin{array}{c}7 \\
(12,5)\end{array}$ & $\begin{array}{l}\text { Saya tidak } \\
\text { punya tenaga } \\
\text { sama sekali }\end{array}$ \\
\hline
\end{tabular}

Deskripsi skor Chronic Obstructive Pulmonary Disease Assesment Test (CAT) rerata 22,6 standar deviasi 7,9 , nilai tengah 24, skor terendah 0 dan skor tertinggi 40. Deskripsi kategori kualitas hidup pasien PPOK sebagian besar adalah buruk $(60,7 \%)$, urutan kedua adalah sedang $(23,3 \%$, urutan ketiga buruk sekali $(8,9 \%)$, dan urutan keempat baik $(7,1 \%)$. Informasi selengkapnya terdapat pada tabel 7 dan 8 di bawah ini.

Tabel 7. Deskripsi Skor CAT Pasien PPOK $(n=56)$

\begin{tabular}{lllllc}
\hline & Rerata & SD & Median & Min - Maks & 95\% Cl \\
\hline CAT & 22,61 & 7,9 & 24 & $0-40$ & $20,5-24,7$ \\
\hline
\end{tabular}

Tabel 8 Deskripsi Kategori Kualitas Hidup Pasien PPOK ( $n=56)$

\begin{tabular}{lcc}
\hline \multicolumn{1}{c}{ Kualitas Hidup } & $\mathbf{n}$ & \% \\
\hline Buruk Sekali & 5 & 8,9 \\
Buruk & 34 & 60,7 \\
Sedang & 12 & 21,4 \\
Baik & 5 & 8,9 \\
Total & 56 & 100,0 \\
\hline
\end{tabular}


Kualitas hidup pasien PPOK antara laki-laki dan perempuan dengan uji Mann-Whitney tidak menunjukkan adanya perbedaan yang bermakna $(p=0,316)$, demikian juga kualitas hidup pasien PPOK antara perokok dan bukan perokok menunjukkan hasil yang serupa yaitu tidak ada perbedaan bermakna $(p=0,684)$. Hasil uji Kendall-tau menunjukkan tidak ada korelasi antara usia dengan kualitas hidup pasien PPOK $(r=-0,023, p=0,833)$, dan tidak ada korelasi antara lama menderita PPOK dengan kualitas hidup pasien PPOK $(r=-0,13, p=0,914)$. Informasi selengkapnya terdapat pada tabel 9,10 dan 11 di bawah ini.

Tabel 9. Perbedaan Kualitas Hidup Laki-laki dan Perempuan

\begin{tabular}{lllll}
\hline \multicolumn{1}{c}{ Jenis Kelamin } & $\mathbf{n}$ & \multicolumn{1}{c}{ Mean Rank } & Sum of Ranks & \multicolumn{1}{c}{$\boldsymbol{p}$} \\
\hline Perempuan & 24 & 30,71 & 737 & 0,316 \\
Laki-laki & 32 & 26,84 & 859 & \\
\hline
\end{tabular}

Tabel 10. Perbedaan Kualitas Hidup Merokok dan Tidak Merokok $(n=56)$

\begin{tabular}{llllc}
\hline \multicolumn{1}{c}{ Smooking } & $\mathbf{n}$ & \multicolumn{1}{c}{ Mean Rank } & Sum of Ranks & $\boldsymbol{p}$ \\
\hline Tidak merokok & 24 & 29,40 & 705 & 0,684 \\
Merokok & 32 & 27,83 & 890 & \\
\hline
\end{tabular}

Tabel 11. Hubungan Umur dan lama menderita dengan Kualitas Hidup Pasien PPOK ( $n=56)$

\begin{tabular}{llll}
\hline & \multicolumn{1}{c}{$\boldsymbol{p}$} \\
\hline Umur & $-0,023$ & 0,833 & \\
Lama PPOK & $-0,013$ & 0,914 \\
\hline
\end{tabular}

\section{Karakterisitik Pasien PPOK}

Karakteristik responden penderita PPOK berupa jenis kelamin menunjukkan hasil jenis kelamin lakilaki lebih tinggi dibanding dengan perempuan. Temuan ini sejalan dengan Riskesdas Tahun 2013, ditemukan prevalensi PPOK yang lebih tinggi pada laki-laki $(4,2 \%)$ dibanding perempuan (3,3\%). Selain itu, diketahui bahwa hasil studi di 28 negara tahun 1990 sampai dengan 2004 menunjukkan bahwa prevalensi PPOK lebih tinggi pada laki-laki dibandingkan perempuan dan lebih tinggi pada usia $\geq 40$ tahun dibandingkan yang berusia $<40$ tahun (GOLD, 2020b). Selaras hasil riset sebelumnya sebagian besar pasien PPOK 53,3\% adalah laki-laki (Huriah \& Ningtias, 2017). Hasil penelitian lainnya menunjukkan $80 \%$ pasien PPOK adalah laki-laki (Ritianingsih, 2017). Laki-laki berpelunag besar untuk mengalami PPOK.

Pasien PPOK sebagian besar adalah merokok. Selaras riset sebelumnya $56,7 \%$ merokok (Huriah \& Ningtias, 2017). Hasil studi lainnya menunjukkan $75 \%$ pasien PPOK adalah perokok (Tarigan \& Juliandi, 2018). Asap rokok akan menstimulasi peradangan bronkus secara terus-menerus yang dapat mengakibatkan penurunan ventilasi dan difusi sehingga menurunkan asupan oksigen (Price \& Wilson, 2006). Faktor resiko utama PPOK adalah pajanan asap rokok, baik perokok aktif maupun perokok pasif. Faktor risiko lain PPOK adalah riwayat terpapar polusi udara di luar rumah seperti: debu, bahan kimia, asap di lingkungan kerja, dan polusi udara di dalam ruangan, faktor genetik, ketidaknormalan perkembangan paru-paru, usia, dan hiperaktivitas bronkus (Gold, 20017, Vestbo et.al., 2013). PPOK lebih tinggi pada laki-laki (4,2\%) dibanding perempuan (3,3\%) (Riskesdas 2013). Hasil studi di 28 negara tahun 1990 sampai dengan 2004 menunjukkan bahwa prevalensi PPOK lebih tinggi pada laki-laki dibandingkan perempuan dan lebih tinggi pada usia $\geq 40$ tahun dibandingkan yang berusia $<40$ tahun (GOLD, 2020b).

Menghirup asap rokok atau partikel berbahaya lainnya dapat menyebabkan peradangan paru-paru. Peradangan tersebut merupakan mekanisme normal yang sepertinya berubah pada pasien yang mengalami PPOK. Respon terhadap peradangan kronis dapat memicu kerusakan jaringan (menyebabkan emphysema) dan gangguan pada mekanisme pertahanan tubuh (menyebabkan fibrosis saluran nafas kecil). Hal inilah yang menyebabkan adanya sumbatan udara dan pembatasan 
aliran udara secara progressif pada PPOK. Terdapat beberapa mekanisme yang menyebabkan terjadinya PPOK.

PPOK dilatarbelakangi oleh beberapa keadaan patologi seperti bronkitis kronik, emfisema, dan asma kronik Pada bronkitis kronik terdapat pembesaran kelenjar mukosa bronkus, metaplasia sel goblet, inflamasi, hipertrofi otot polos pernapasan serta distorsi akibat fibrosis. Epitelium bronkial mengalami peradangan dalam jangka waktu lama dengan hipertrofi kelenjar mukus dan peningkatan jumlah sel goblet. Terjadi juga kerusakan silia dan pergerakan mukosiliari, viskositas mukus, dan sekresinya meningkat, yang kemudia akan menyebabkan hambatan untuk mengeluarkannya (gangguan ekspektoransi). Pembesaran kelenjar mukus dapat diakibatkan karena infkesi, dan inflamasi yang berulang dapat menyebabkan kerusakan struktural yang irreversibel dari dinding saluran napas. Kerusakan ini akan menimbulkan luka dan membuat saluran napas perifer mengalami penyempitan dan penghambatan. Kondisi tersebut dapat berkembang menjadi obstruksi saluran napas yang parah, yang kemudian disebut PPOK.

\section{Kualitas Hidup Pasien PPOK}

Studi yang kami lakukan menemukan sebagian besar kuliatas hidup pasien PPOK dalam kondisi buruk sebesar 34\%. Sejalan dengan penelitian ini Xiao et.al (2020) bahwa ada korelasi signifikan antara eksaserbasi dan kuliatas aktivtas fisik pasien PPOK dengan penurunan kualitas hidup. Kualitas hidup merupakan harapan seseorang terhadap kehidupannya dibandingkan dengan realita yang dihadapinya. Kualitas hidup bersifat subjektif dan bervariasi sesuai dengan persepsi individu terhadap kesehatan dan kemampuan untuk mempertahankannya, oleh karena itu kualitas hidup sangat sulit didefinisikan (Lubkin \& Larsen, 2006). Perubahan fisiologis dan kondisi kronis pada kesehatan sangat berpengaruh terhadap kualitas hidup seseorang (Black \& Hawks, 2009).

Kualitas hidup menurut WHO adalah persepsi individu tentang posisi mereka dalam kehidupan dalam konteks budaya dan sistem nilai di mana mereka hidup dan dalam kaitannya dengan tujuan, harapan, standar dan kekhawatiran mereka. Hal ini merupakan konsep luas yang dipengaruhi oleh cara yang kompleks oleh kesehatan fisik seseorang, keadaan psikologis, kepercayaan pribadi, hubungan sosial dan hubungannya dengan fitur yang menonjol di lingkungan mereka (Peterson \& Bredow, 2004). Kualitas hidup merupakan persepsi individu dalam hidup ditinjau dari konteks budaya dan sistem nilai dimana ia tinggal, berhubungan dengan standar hidup, harapan, kesenangan, dan perhatian mereka.

Temuan lain pada penelitian ini pada uji bivariat pada ketiga variabel karakteristik mencakup jenis kelamin, kebiasaan merokok dan usia menujukkan tidak adanya perbedaan Pasien PPOK terjadi peningkatan beban kerja pernapasan yang menimbulkan sesak napas sehingga pasien mengalami penurunan kualitas hidupnya. Seiring semakin meningkatnya prevalensi PPOK dan sifat penyakitnya yang kronis, fokus penanganan PPOK bergeser penekanannya dari pengobatan dan memperpanjang harapan hidup kini mulai berfokus pada peningkatan kualitas hidup. Kualitas hidup merupakan gabungan dari beberapa dimensi yang dialami oleh pasien yang menderita suatu penyakit. Pasien PPOK akan mengalami penurunan kualitas hidup karena dampak negatif dari penyakit tersebut. Keterbatasan aktifitas merupakan keluhan utama pasien PPOK yang mempengaruhi kualitas hidup. Padahal sebagian pasien masih dalam usia produktif namun tidak dapat bekerja maksimal karena sesak napas yang kronis. Sesak napas dan pola napas yang tidak selaras akan menjadi penyebab pasien PPOK menjaid cemas, panik dan akhir frustasi. Gejala ini merupakan penyebab utama pasien PPOK mengurangi aktifitas fisiknya untuk menghindari sesak napas yang berujung pada penurunan kualitas hidup. Kualitas hidup pasien PPOK berfluktuasi, karena dipengaruhi oleh kesehatan fisik, psikologis, tingkat kemandirian, hubungan sosial, kepercayaan pribadi dan hubungan mereka dengan lingkungan. 


\section{SIMPULAN DAN SARAN}

Pasien PPOK sebagian besar adalah laki-laki $(57,1 \%)$, umur median 45 tahun, paling banyak berpendidikan SMP $(30,4 \%)$, paling banyak memiliki pekerjaan swasta $(42,9 \%)$, lama menderita PPOK median 1 tahun, frekuensi napas rerata 23,6 permenit, komorbiditas terbanyak adalah jantung dan hipertensi (37,5\%), bentuk torak terbanyak normal (82,1\%), dan sebagian besar merokok (57,1\%). Skor Chronic Obstructive Pulmonary Disease Assesment Test (CAT) rerata 22,6. Kategori kualitas hidup pasien PPOK sebagian besar adalah buruk $(60,7 \%)$. Saran Pasien PPOK perlu melakukan kunjungan ke Ners atau pelayanan kesehatan untuk memperoleh edukasi manajemen self-care pada kondisi kroniknya agar dapat memperbaiki kualitas hidupnya. Keluarga sebagai caregiver pasien PPOK perlu memberikan dukungan fasilitas untuk berkunjung ke Ners atau pelayanan kesehatan agar dapat meningkatkan manajemen self-care pasien. Peneliti selanjutnya perlu menggali faktor-faktor yang berhubungan dengan kualitas hidup pasien PPOK.

\section{DAFTAR PUSTAKA}

Black, J. M., \& Hawks, J. H. (2009). Medical-Surgical Nursing Clinical Mangement for Positive Outcomes (R. G. Carroll \& S. A. Quallich Eds. Eighth ed. Vol. 1-2). St. Louis, Missouri: Saunders, Elsevier Inc.

Gold, G. I. f. C. O. L. D. (2020a) Global Strategy for The Diagnosis, Management, and Prevention of Chronic Obstructive Pulmonary Disease (2020 Report). In: Global Initiative for Chronic Obstructive Lung Disease, Inc.

Gold, G. I. f. C. O. L. D. (2020b) Pocket Guide to COPD Diagnosis, Management, and Prevention a Guide for Health care Professionals 2020 Report. In: Global Initiative for Chronic Obstructive Lung Disease, Inc.

Hamid, A. Y. S. (2008). Buku Ajar Riset Keperawatan: Konsep, Etika, \& Instrumentasi (2 ed.). Jakarta: Penerbit Buku Kedokteran EGC.

Huriah, T., \& Ningtias, D. W. (2017). Pengaruh Active Cycle Of Breathing Technique Terhadap Peningkatan Nilai VEP1, Jumlah Sputum, dan Mobilisasi Sangkar Thoraks Pasien PPOK. IJNP (Indonesian Journal of Nursing Practices), 1(2), 44-54.

Kumar, V., Abbas, A. K., Aster, J. C., Robbins, S. L., Cornain, S., \& Nasar, I. M. (2015). Buku ajar patologi Robbins.

Lewis, S. L., Dirksen, S. R., Heitkemper, M. M., \& Bucher, L. (2013). Medical-Surgical Nursing: Assessment and Management of Clinical Problems, Single Volume: Elsevier/Mosby.

Lubkin, I. M., \& Larsen, P. D. (2006). Chronic Illness Impact and Interventions (6th ed.). Sudbury, Massachusetts: Jones and Bartlet Publishers.

Morishita-Katsu, M., Nishimura, K., Taniguchi, H., Kimura, T., Kondoh, Y., Kataoka, K., . . . Hasegawa, Y. (2016). The COPD assessment test and St George's Respiratory Questionnaire: are they equivalent in subjects with COPD? International journal of chronic obstructive pulmonary disease, 11, 1543-1551. doi:10.2147/COPD.S104947

Peterson, S. J., \& Bredow, T. S. (2004). Middle Range Theory. Philadelphia: Lippincott Williams \& Wilkins.

Polit, D. F., \& Beck, C. T. (2012). Nursing Research: Generating And Assesing Evidence For Nursing Practice (Ninth ed.). Philadelphia: Wolters Kluwer Health; Lippincott Williams \& Wilkins. 
Price, S. A., \& Wilson, L. M. (2002). Pathophysiology: Clinical Concepts of Disease Processes (6 ed. Vol. 1-2). St. Louis, Missouri: Mosby inc.; Elsevier Inc.

Price, S. A., \& Wilson, L. M. (2006). Pathophysiology: Clinical Concepts of Disease Processes (7 ed. Vol. 1-2). St. Louis, Missouri: Mosby inc.; Elsevier Inc.

Ritianingsih, N. (2017). Lama Sakit Berhubungan Dengan Kualitas Hidup Pasien Penyakit Paru Obstruksi Kronis (PPOK). Jurnal Kesehatan Bakti Tunas Husada: Jurnal Ilmu-ilmu Keperawatan, Analis Kesehatan dan Farmasi, 17(1), 133-138.

Rosha, P. T. (2017). Faktor-Faktor yang Mempengaruhi Kualitas Hidup Pasien Rawat Jalan Penyakit Paru Obstruksi Kronis (PPOK) di Poli Paru RS PKU Muhammadiyah dan RSUD Kabupaten Temanggung. Universitas Gadjah Mada,

Tarigan, A. P. S., \& Juliandi, J. (2018). Pernafasan Pursed Lip Breathing Meningkatkan Saturasi Oksigen Penderita PPOK Derajat II. Jurnal On Line Keperawatan Indonesia, 1(2), 39-46.

Xiao, T., Wu, K., Chen, Y., Qiu, H., Ruan, X., Wang, N., ... Fu, C. (2020). Quality of life and its associated factors for mild chronic obstructive pulmonary disease patients of urban community settings. Annals of Palliative Medicine, 9(4), 1420-1430. https://doi.org/10.21037/apm-19-655 